\title{
Ю.А. Аверьянов \\ Источники по истории суфийской обители Сейида Али Султана (г. Димотика, Греция)
}

Сейид Али Султан, известный также под прозвищем Кызыл-Дели («Красный безумец», «Красный удалец»), - знаменитый османский воин-дервиш XIV в. Его обитель во Фракии (ныне на территории Греции) возникла во времена османского султана Баязида I Молниеносного (1389-1402 гг.), вошедшего в османскую историю в качестве одного из наиболее смелых и талантливых султанов-полководцев. В Турции последователи Сейида Али Султана (относящиеся к суфийскому братству бекташийа) проживают в Эдирне, Малатье и Кютахье (а также в окрестностях этих трех городов). Обитель Сейида Али Султана в г. Диметока (греч. Дидимотихон, Димотика) была одной из главных обителей братства бекташийа. В начале XVI в. настоятелем этой обители (текке) был крупнейший реформатор бекташи, «второй старец» (пuр-u сани) Балым Султан (ум. 1516 г.). По-видимому, именно в этой обители примерно в то же самое время был составлен агиографический памятник на староосманском языке, повествующий о жизни ее основателя — «Вилайет-наме-и Сейид Али Султан». Это произведение, наряду с очень немногочисленными архивными документами XV в., является источником, наиболее полно повествующим о жизни этого полулегендарного персонажа. Автором «Вилайет-наме» считается некий дервиш Джезби, но о времени его жизни приходится лишь догадываться.

Рукописи этого сочинения (всего 4) хранятся в библиотеках Турции и Египта. В Турции известны три рукописи: в Национальной библиотеке в Анкаре ${ }^{1}$; в Библиотеке Ататюрка в Стамбуле 2 ; в Библиотеке имени Сермета Чифтера при банке «Япы креди» в Стамбуле 3 . Известный турецкий ученый-османист А. Гёльпынарлы (ум. 1982 г.) также утверждал, что является обладателем одной из рукописей «Вилайетнаме-и Сейид Али Султан», копии с которой он предоставил главе од- 
жака Кызыл Дели Лютфи Айкурту Баба и немецкой исследовательнице турецкого происхождения С. Фароки, но о судьбе самого оригинала из личной коллекции Гёльпынарлы ничего сказать невозможно. Все турецкие рукописи очень близки по содержанию друг к другу и восходят к одному протографу. Все они переписаны в позднеосманский период. Каирская рукопись «Вилайет-наме» происходит из обители Кайгусуза Абдала на горе Мукаттам. Эта рукопись по содержанию отличается от рукописей, хранящихся в Турции. Так, она показывает Сейида Али Султана современником эмира Орхана Гази (1324/26 - 1359/62 гг.), а не его внука Баязида и делает его соратником сына Орхана — полководца Сулеймана-паши (ум. 1357 г.).

«Вилайет-наме-и Сейид Али Султан» имеет большое значение как для изучения суфийских групп, переселявшихся на Балканы в XIV в., так и для истории османских завоеваний и определения места и роли странствующих дервишей («дервишей-воинов») в этих завоеваниях. «Вилайетнаме» с разных точек зрения исследовали турецкие ученые А.Я. Оджак [Ocak, 1997. S. 54-55], Х. Шахин [Şahin, 2008. S. 547-566; Şahin, 2009. S. 48-50], а также издатели текста «Вилайет-наме» Б. Нойан [Noyan, 1999] (первое издание текста, в которое вкралась масса ошибок) и Р. Йылдырым [Yıldırım, 2007]. Последний из них провел сравнительный анализ турецких рукописей памятника с каирской рукописью и приложил к своему изданию факсимиле анкарской рукописи.

Кроме «Вилайет-наме-и Сейид Али Султан» о персонаже по имени Кызыл-Дели имеются сведения в другом средневековом памятнике бекташи - «Вилайет-наме-и Абдал Муса Султан», в котором говорится, что дервиш Кызыл-Дели служил преемнику Хаджи Бекташа - Абдалу Мусе, действовавшему в юго-западной части Анатолии (Ликия), и затем был послан им в поход против «неверных» вместе с войском айдынского эмира Гази Умур-паши (убит в 1348 г.). Текст этого «Вилайет-наме» был издан в Анкаре А. Гюзелем [Abdal Musa, 1999]. Сейид Али Султан (чаще под именем Кызыл-Дели) упоминается во многих духовных гимнах бекташи, которые были собраны и опубликованы в 1944 г. С.Н. Эргуном [Ergun, 1944. S. 177]. Это нефесы таких средневековых поэтов, как Кул Химмет, Вирани, Геда Муслу (Мусли), Вели Деде, Юсуф Деде.

Из европейских ученых к образу Сейида Али Султана первым обратился в 1937 г. английский исследователь Дж. Бирдж [Birge, 1965. Р. 52-56]. Он получил копию рукописи «Вилайет-наме-и Сейид Али Султан» от главы бекташи Албании Нийази Деде (это была копия каирской рукописи). На основании этого манускрипта Бирдж связал Сейида Али Султана с Хаджи Бекташем Вели и с Орханом Гази и сделал предположение, что дервиши-бекташи принимали активное участие в османских завоеваниях на Балканах.

Турецкий историк О.Л. Баркан в 1942 г. опубликовал два архивных документа, относящихся к ранней истории обители Сейида Али Султана. Это записи в дефтере Пашаэли № 732, в которых говорится о 
том, что султан Баязид I выделил завийе Сейида Али Султана «в кормление» («для пропитания всех странствующих и путешествующих») земли Дары Бюкю, Тыфиллю Виран и Бююк Виран [Barkan, 1942. S. 339-340].

М.Т. Гёкбильгин в своем исследовании, посвященном вакфам и другим земельным владениям в Османской Фракии, привел текст еще нескольких архивных документов из Османского архива премьер-министра, относящихся к эпохе претендента на османский трон Мусы Челеби (ум. 1416 г.). В этих документах вместо прозвища Кызыл-Дели мы встречаем лакаб Кызыл-Диване (с тем же значением). Там упоминаются и имена потомков («детей») Кызыл-Диване [Gökbilgin, 1952. S. 183-186].

Фольклорист Н. Кумахмедоглу собрал в 40-е годы XX в. народные рассказы об абдалах (странствующих дервишах) Кызыл-Дели Султана, проживавших в таких городах, как Искилип, Самсун, Кырыккале, Малатья, Мараш и Адана и признававших над собой власть оджака из деревни Шейх-Хасанлы под Малатьей [Kumahmedoğlu, 1948. С. 23-32]. Эти полевые данные показывают, что личность Кызыл-Дели была популярна не только на Балканах, но и среди абдалов в разных уголках Анатолии. Среди европейских авторов Сейиду Али Султану посвятили отдельные научные статьи И. Бельдичану-Штайнхер [Beldiceanu-Steinherr, 1971. P. 275-276] и С. Фароки [Faroqhi, 1976. Р. 69-96]. Первая из этих исследовательниц пыталась отождествить Сейида Али Султана с османским военачальником XIV в. Хаджи Ильбеги (вначале, возможно, бывшим самостоятельным туркменским предводителем). С. Фароки интересовало больше социально-экономическое положение обители Кызыл-Дели в позднеосманский период в сравнении с двумя другими обителями бекташи - Койун Баба и Абдал Муса.

Только А.Я. Оджак предложил свое видение внешнего облика Сейида Али Султана, бывшего, по его мнению, «полуголым торлаком», вооруженным мечом, как и его ближайший друг Сейид Рустем [Ocak, 1992. S. 95-96; о торлаках см. там же. S. 115-116, 126-129]. В связи с оживлением культурной деятельности алевитов в Турции в 90-е гг. прошлого века появилось несколько работ алевитских авторов, передающих легендарные сведения о Кызыл-Дели и рассказывающих о тех или иных сообществах его последователей во Фракии и в Анатолии. Так, Н. Бирдоган в своем труде о расселении алевитов в Турции, ссылаясь на устные сообщения баба бекташи Тургута Коджа, говорит о том, что в районе Эдирне Сейида Али Султана считают не только важным мистическим персонажем, участвующим в джеме (собрании) Сорока святых, но и «мастером» традиционной турецкой борьбы (гюреш), разработавшим правила этой борьбы и установившим в своей обители принцип безбрачия [Birdoğan, 1992. S. 58-59].

Дж. Кафадар в своей вышедшей в США на английском языке монографии попытался представить Сейида Али Султана в историческим окружении, остановившись более подробно на личностях его сподвижников [Kafadar, 1995. Р. 115-117]. 
В 1999 г. И. Бельдичану-Штайнхер вновь обратилась к личности Сейида Али Султана и к истории его обители, опубликовав в своей большой статье в сборнике «Via Egnatia» ряд документов, касающихся этой обители, из османских налоговых описей (тахрир дефтерлери). На этот раз она отказалась от отождествления Сейида Али Султана с Хаджи Ильбеги и сосредоточилась на попытках написания связной истории его обители [Beldiceanu-Steinherr, 1999. Р. 57-72].

Имеются данные о существовании еще одной обители Сейида Али Султана, в Болгарии, в районе Кырджали [Кауа, 2002. S. 511-525]. Составлен и список деревень во Фракии, в которых продолжается традиция («путь») Кызыл-Дели. В последние годы некоторыми турецкими авторами изучается образ Кызыл-Дели в алевитской поэзии Анатолии [Bahtiyar, 1999. S. 148-150]. История текке Сейида Али Султана на основе османских архивных материалов стала предметом монографии А. Хезарфена [Hezarfen, 2006]. Ш. Коджа в своей статье о Сейиде Али Султане называет его именем Хызыр Лале (так звали приемного сына («сына дыхания») Хаджи Бекташа), но в то же время полагает, что под этим именем скрывался хуруфитский миссионер Али уль-Ала [Коса Ş., 2005. S. 276-290]. Современные представления бекташи и алевитов о Кызыл-Дели и нынешнее положение оджака Кызыл-Дели и его ответвлений в различных районах Турции нашли отражение в книге А. Айдына, который лично посетил многие святилища бекташи и занимался подготовкой радио- и телепрограмм, посвященных традициям бекташи [Aydın, 2008]. Ему удалось обнаружить последователей Кызыл-Дели в Центральной Анатолии, в районе Кютахьи.

Учитель из греческого города Гюмюльджине (Комотини) Ахмет Кавак в своей книге о Сейиде Али Султане, изданной на турецком языке в 2006 г., передает легендарные сведения о Сейиде Али Султане и дает описание его обители, состоящей из «верхнего» и «нижнего» текке, расположенных на склонах горы Танры-дагы [Kavak, 2006]. Он делится в книге своими наблюдениями о современном состоянии обители, гробницы Сейида Али Султана и суфийского кладбища при ней. А. Кавак также сообщает, что в 1940-41 гг., во время нашествия греческих полукочевников-каракачанов, обитель была превращена последними в загон для овец.

Одна из гробниц (скорее всего, макам) Сейида Али Султана находится в деревне Меркез Окчу близ Кютахьи, в одном тюрбе с макамом Хаджима Султана. Прослеживается связь между Сейидом Али Султаном и тюркским племенем балабан, проживавшим в окрестностях Малатьи и участвовавшим в завоевании Румелии в XIV в. Этот вопрос разрабатывает монография В. Озгюля, опубликованная в 2010 г. [Özgül, 2010. S. 191-314].

В российской науке, насколько нам известно, Сейиду Али Султану не было посвящено ни одной работы. Восполняя этот пробел, следует обратиться к изучению как агиографических, так и архивных до- 
кументов и сообщений османских хроник о нем. Наиболее полной на сегодняшний день монографией о Сейиде Али Султане остается книга Ризы Йылдырыма, увидевшая свет в 2007 г. в Анкаре и основанная на анализе «Вилайет-наме-и Сейид Али Султан». Р. Йылдырым в наши дни, безусловно, является крупнейшим специалистом по личности Сейида Али Султана, хотя не со всеми высказываемыми им положениями можно согласиться.

Основные выводы Р. Йылдырыма сводятся к тому, что Сейид Али Султан - один из наставников братства бекташийа, чье прозвище Кызыл-Дели объясняется турецким названием реки, на берегу которой была построена его обитель (Кызыл-Дели). Легенда объясняет прозвище этого суфия тем, что, когда он был поваром (ашчи-баба) в обители Хаджи Бекташа и послал своего дервиша Кайгусуза Абдала собирать дрова, тот замешкался и не принес дров вовремя, и тогда Сейид Али Султан, чтобы приготовить пищу для собратьев, сунул свои ноги в очаг и таким образом поддерживал огонь. Хаджи Бекташ, увидев такую самоотверженность своего дервиша, нарек его именем Кызыл-Дели (так как его ноги покраснели от ожогов) и отправил его в Румелию, где он и основал свою собственную обитель. Звание ашчи-баба является вторым по значению в суфийской иерархии братства бекташийа. В любом случае образ Кызыл-Дели предстает перед нами именно таким, каким его видят сами адепты братства. Р. Йылдырым разделяет бекташийские источники, повествующие о Кызыл-Дели (Сейиде Али Султане) на четыре группы: 1) «Вилайет-наме-и Сейид Али Султан», 2) духовные стихи-нефесы, 3) трактаты, вышедшие из-под пера баба бекташи в конце XIX - начале XX в., 4) устные сказания бекташи [Yıldırım, 2010a. S. 59-60]. Эти источники взаимосвязаны друг с другом, но плохо вписываются в историческую канву, строящуюся на сообщениях османских хроник, поэтому их сопоставление не всегда приводит к убедительным результатам. Наиболее приемлемый выход - рассматривать данные традиции отдельно, как и поступает Р. Йылдырым.

«Вилайет-наме-и Сейид Али Султан» основывается на устных сказаниях об этом шейхе, передававшихся его дервишами на протяжении XV-XVI вв. Отдельные сказания о Кызыл-Дели отразились и в нефесах поэтов-бекташи. Общее число этих стихотворений - не менее 40. Нефесы нельзя назвать «историческими песнями», они отражают скорее религиозно-мифологические представления общины бекташи. Авторство подобных произведений не может быть точно установлено, поскольку они также долгое время передавались из уст в уста, и в них могли вноситься изменения. И «Вилайет-наме», и нефесы образуют «коллективную память» бекташи, внутри которой и сохраняется героический образ Сейида Али Султана.

Традиция настаивает на хорасанском происхождении Сейида Али Султана. Он был представителем группы Сорока (Кырклар; в данном случае, скорее всего, какой-то тайный мужской союз, а не «Сорок 
святых»). Во сне ему является Пророк, который говорит о необходимости им всем отправиться в страну Рум (Малую Азию) на помощь эмиру Орхану Гази (или Баязиду I). Эти сорок воинов поступают в соответствии с пожеланием Пророка и оказываются в Руме. Ни о предках Сейда Али Султана, ни о его родословной в «Вилайет-наме» ничего не сказано (хотя Пророк признает его своим потомком).

В нефесах бекташи утверждается, что Сейид Али Султан происходил из рода Пророка через его внука - имама Хасана. Так, Геда Муслу, живший в XVII в. и получивший посвящение в обители Кызыл-Дели, сообщает:

Его происхождение - из Хоя, Из царства Хорасана.

Предок нашего пира - Шах Имам Хасан.

Опирайся на наставника своего, Геда Муслу, Пусть в день Суда его рука будет в твоей руке [Noyan, 2000. S. 294-295].

Поздний бекташийский автор Ахмет Рифат-эфенди считает отцом Сейида Али Султана святого человека (эрен) из Хорасана по имени Сейид Хасан Ата. Те же сведения позднее приводит и М. Ойтан [Oytan, 2007. S. 350]. Б. Нойан, напротив, полагал, что отца Сейида Али Султана звали Сейид Хусейн Ата; он указывает примерные даты жизни своего героя - 1310-1402 гг. [Noyan, 1999. S. 3]. Ясно, что эти имена - Хасан и Хусейн - нужно связать с именами внуков Пророка Мухаммада; вряд ли они имеют какое-либо отношение к реальным родителям Сейида Али Султана. Народное предание называет братьями Сейида Али Султана Абдала Мусу и Эмира Султана, похороненного в Бурсе [Yıldırım, 2010a. S. 65]. У Кызыл-Дели (Сейида Али Султана) было трое сыновей - Шабан Абдал, Бал Абдал и Кара Абдал (устные рассказы алевитов Малатьи). Фракийские бекташи полагают, что его сыновей звали иначе - Ресуль Бали, Мюрсель Бали и Кара Баба. Нынешние деде из оджака Кызыл-Дели считаются потомками его младшего и рано умершего сына Кара Баба. Алевиты Малатьи приписывают Кызыл-Дели еще одного брата - Али Сейди, и сестру - Баджи Султан. Наконец, Джемаль эд-Дин Челеби, писавший в 1910 г., называет Сейида Али Султана сыном Хаджи Бекташа, соединяя в одно целое трех персонажей - Хызыра Бали, османского военачальника Тимурташа (ум. 1404 г.) и Сейида Али Султана [Там же. S. 66].

Сын Кызыл-Дели по имени Шабан упоминается в османской налоговой описи 1456 г. в качестве распорядителя его вакфа (значит, в это время ему едва ли могло быть больше 70 лет) [Beldiceanu-Steinherr, 1999. Р. 71]. В налоговой описи 1486 г. перечисляются другие потомки (внуки?) Кызыл-Дели: Гюльшехри, Ильяс, Биляль, Исхак, Синан (о которых народная традиция ничего не знает). Возможно, все они были сыновьями Шабана Деде. 
Согласно «Вилайет-наме», сорок воинов во главе с Сейидом Али Султаном прибыли из Хорасана в обитель Хаджи Бекташа Вели в Карагююке (которая, следовательно, тогда уже существовала) и получили его благословение на поход в Румелию. Святой пир опоясал их мечами. Хаджи Бекташ назначил Сейида Али Султана предводителем Сорока, Эмира Султана - знаменосцем, Сейида Рустема - войсковым судьей, Абд ас-Самеда - имамом, Сейида Ахмеда — проводником, Сейида Хамзу, Сейида Фурки и Уфки - трубачами или при стенобитных орудиях (боразанджи). После этого Хаджи Бекташ направил всех сорок воинов (многие из них, как мы видели, были сейидами - потомками Пророка) в ставку османского эмира. На этом его роль в тексте «Вилайет-наме» заканчивается (ни о каком родстве Хаджи Бекташа с Сейидом Али Султаном здесь нет и речи). В нефесе Кул Химмета говорится, что Хаджи Бекташ передал Кызыл-Дели свой «венец» (тадж), то есть суфийский колпак [Коса T., 1990. S. 167]. В поздних трактатах бекташи также сказано о «духовных знаках и разрешении», полученном Сейидом Али Султаном во время пребывания в обители Хаджи Бекташа от самого пира. Но мы знаем, что Хаджи Бекташ (ум. ранее 1295 г.) не был современником Орхана Гази и не мог направить к нему Сейида Али Султана и его воинов-гази. В большинстве рукописей «Вилайет-наме-и Хаджи Бекташ» также ничего не говорится о халифе Хаджи Бекташа по имени Сейид Али Султан или Кызыл Дели.

О Сейиде Али Султане сохранились довольно смутные воспоминания в трудах раннеосманских авторов, писавших в летописном ключе. Так, в «Дустур-наме» Энвери, законченном в 1465 г., говорится, что среди приближенных эмира Орхана был некий сейид, его духовный пастырь, облаченный в красный колпак. Там же рассказывается о переправе 70 всадников во главе с принцем Сулейманом-пашой на европейский берег, причем его также сопровождал некий святой муж (эр), облаченный в красный головной убор. При осаде крепости Гелиболу упомянуты 40 османских всадников в тюрбанах красного цвета [Düsturname-i Enveri, 2003. S. 24-27]. В вакуфной грамоте (вакфийе) Мурада I, составленной в 60-е гг. XIV в., сказано, что этот султан женился на «дочурке (кызджугаз) моего родственника Сейди Султана» [Öz, 1941. S. 243]. Болгарский просветитель и философ Константин Костенецкий в своей биографии сербского деспота Стефана Лазаревича, написанной в 1431 г. на церковно-славянском языке, рассказывает, что Орхан обещал своему шейху по имени Сеидия по одному из каждых десяти городов, которые будут захвачены его воинами на Балканах. Сулейманпаша, переправившись в Европу возле Галлиполи, открыл туда дорогу Сеидии и другим (духовным?) лицам. Затем Сулейман, Сеидия и Орхан скончались, и к власти пришел младший сын последнего - Мурад [Kosteneçki, 2008. S. 19, 51].

Османский историк XVI в. Йусуф ибн Абд аль-Лятиф, автор труда «Субхат аль-абрар» и современник султана Селима II (1566-1574 гг.), 
сообщает: «Был безумец (диване) в Вардар-гичеси, он появился после взятия Гелиболу. Он шел вместе с мусульманами и, куда бы ни направлялся Гази Сулейман-паша, всюду следовал за ним. Дабы солнце не пекло ему затылок, он пришил кусок войлока в два локтя длиной к одной стороне старого таджа Умур-бега. Затем пехотинцы-гази тоже стали носить такой войлок, и потом, когда пришло время янычар, детей торговцев (?), они сделали для себя такой же головной убор. Записывать в пехоту и носить белую шапку и красную шапку стали во времена Орхана Гази» [Akın, 1968. S. 50-51].

Как видно из вышеперечисленных отрывков, авторы анналов связывают упомянутого ими сейида с правлением Орхана и с походами его старшего сына, Сулеймана, а также с переселением в Европу какихто групп тюркского населения. Только относительно поздний автор, Йусуф, склонен считать этого святого человека (если вообще речь идет о нем, а не о другом персонаже) помешанным. Особое внимание историков османского круга (но не болгарина Константина) приковывает к себе красный головной убор (тюрбан) этого мужа, который, видимо, отражал определенную символику сообщества гази. Следует отметить, что литературные приемы описания походов гази во многом совпадали у суфийских и несуфийских османских авторов. Сведения историков заставляют предположить, что Сейид Али скончался вскоре после смерти эмира Орхана.

Сейида Али под именем Али Сейди восхваляет суфийский автор XV в. Мухйи-д-Дин Челеби в своем знаменитом сочинении «Хызыр-наме», в котором он изображает свой приход на мистическое собрание умерших анатолийских святых-эренов, живших в предшествующие века, и духовную беседу с ними ${ }^{4}$.

В поздних суфийских трактатах Сейид Али Султан предстает больше в дервишеской, чем в воинской ипостаси. Некоторое время он якобы прожил в обители Хаджи Бекташа, занимаясь самосовершенствованием. Его поход в Румелию изображается скорее как странствие, чем как завоевание. Ш. Коджа писал, что Сейид Али Султан в 1385-1387 гг. возглавлял основанную им обитель в Диметоке, затем, с 1387 г., стал настоятелем главной обители бекташи - Пир Эви, но в 1389 г. покинул ее, для того чтобы принять участие в Косовской битве, оставив вместо себя настоятелем Хабиба Эмирджи [Коса Ş., 2005. S. 286]. Однако эти даты, по-видимому, не более чем плод фантазии автора, пытавшегося «поместить» своего героя в османскую историю (в «Вилайет-наме-и Сейид Али Султан» Косовская битва вообще не упоминается и об участии в ней Сейида Али Султана не сказано). Иногда заместителем Сейида Али Султана в обители Хаджи Бекташа называют Ресуля Бали. Утверждения Ш. Коджа о безбрачии Сейида Али Султана противоречат архивным данным, говорящим о наличии у него «сыновей» (такого же

4 | Divan-i Muhyiddin Çelebi. İstanbul Üniversitesi Kütüphanesi, Türkçe Yazmalar, № 949, л. 28a. 
мнения придерживаются и устные информанты). Традиция полагает, что Сейид Али Султан был воспитателем и покровителем внука (правнука?) Хызыра Лале (Бали) - Мюрселя Бали, которого считают отцом знаменитого Балым Султана (что хронологически тоже не совсем оправдано). Не исключена возможность того, что Кызыл-Дели недолгое время действительно мог быть настоятелем в обители Хаджи Бекташа (или «исполняющим обязанности» настоятеля, имея сан ашчи-баба).

«Вилайет-наме» настаивает на активной роли Сейида Али Султана и его тридцати девяти собратьев в османском завоевании (фетx) Румелии. Там рассказывается об осаде и захвате ими целого ряда византийских и болгарских крепостей [Yıldırım, 2007. S. 161]. Полностью согласуется с «Вилайет-наме» образ Кызыл-Дели (в данном случае - под именем Кызыл-Вели) в известном нефесе поэта-бекташи XVI в. Вирани:

Мы - абдалы Рума, наш предводитель - Кызыл-Вели, В наших глазах отражение огня нашего - Кызыл-Вели. Мы - обезумевшие соловьи, наш розовый цветник - Кызыл-Вели, Наша религия, наша вера, наша решимость - Кызыл-Вели.

Свет Ахмеда [Пророка], наш рычащий лев - Кызыл-Вели.

Куда ни взглянем, наш взор устремлен к Кызыл-Вели.

[Viranî, 1998. S. 18].

В этом нефесе Кызыл-Вели признается потомком Мухаммада и Али, «предводителем и шахом гази». В нефесе, автором которого считается Пир Султан Абдал (ум. ок. 1588 г.), говорится о том, что Сорок әров переправились в Румелию, причем самым великим из них был Кызыл-Дели, в чьем образе как бы отразился сам «Лев Господа» (Танрынын арсланы) Али. Кызыл Дели высыпал из подола своей рубахи кучу песка в Мраморное море, тем самым перегородив его, и сорок мужей перешли на другую сторону, как посуху. Далее упоминается какой-то эпизод (битва) в «Гусиной долине» (Каз-ова), затянутой туманом, где сердце кафиров дрогнуло (букв. «жир кафиров растаял»), и сообщается об устроении обителей в Румелии и обращении «неверных» в ислам [Aslanoğlu, 2000. S. 395-396]. «Просвещение» Румелии символически уподобляется возжиганию светильников (чераг) в местах поклонения (макам) Сорока святым.

В нефесах подчеркивается воинственный облик Сейида Али Султана и то, что он покорял «неверных» с помощью меча, хотя «сокровенное» начало в его действиях тоже присутствует. В нефесе Геда Муслу (XVII в.) более подробно излагаются чудеса Кызыл-Дели и говорится о его духовной связи (xuммеm) с Абдалом Мусой (здесь именно Абдал Муса опоясывает его деревянным мечом Зульфикар). Кызыл-Дели своим волшебным мечом сначала разрубил камень, затем разделил надвое реку (морской пролив Дарданеллы?) в Богаз-хисаре, чтобы его воины могли переправиться на другой берег. Шах (Кызыл-Дели) заставил по- 
течь кровавый поток (реку Кызыл-Дели), окруживший со всех сторон гору Танры-дагы, на которой впоследствии была построена обитель Сейида Али Султана. Поэт-янычар Геда Муслу вспоминает в своем нефесе и о спутниках Сейида Али Султана - беях и гази, в частности, о бейском семействе Эвренос (которое в устной передаче превратилось в Невруз-беев). Три других топонима, о которых идет речь в нефесе и с которыми связаны чудесные деяния Кызыл-Дели - гора Куру-дагы близ Гелиболу (Галлиполи), местность Бол-йер (Болайыр) на Дарданеллах и местность Сары-Кыз, в которой Кызыл-Дели тоже совершил какое-то чудо (букв. «позвонил (мечом) о камень»). Мы знаем, что святилище «Желтой Девы» (Сары-Кыз) находится в районе Эдремита, на горе Кырклар (Сорока святых), т.е. в относительной близости к тем местам, где разворачивается действие «Вилайет-наме-и Сейид Али Султан», и оно могло послужить исходной точкой для похода героя. Геда Муслу считал Сейида Али своим (и янычарским) пиром [Коса Ş., 1990. S. 219-220].

Из нефесов становится понятным, что, поскольку «кафиры» Румелии сдались на милость Кызыл-Дели, он в какой-то мере является и их заступником («кафиры Румелии нуждаются в твоей милости»). Иногда одно и то же чудо в «Вилайет-наме» и в нефесах бекташи рассказывается по-разному. Так, «Вилайет-наме» сообщает, что КызылДели, будучи на плато Челеби (Челеби-яйласы), пустил из лука стрелу, которая на лету пронзила скалу, и из этой скалы потек источник, названный затем Кайа-пынар [Yıldırım, 2007. S. 174]. В нефесе поэта по прозванию Паки говорится, что шейх, будучи на плато Кору (Кору-яйласы), бросил вертел, пронзив им камень, из которого тотчас же потек источник Баба-пынар [Коса Ş., 1990. S. 894-895]. В целом, в нефесах чудеса шейха излагаются более кратко, часто всего лишь одной строчкой, и перечисляются одно за другим без комментариев (как уже известные слушателям).

К «оригинальным» чудесам Сейида Али Султана можно отнести разрушение им стен вражеской крепости Гелиболу с помощью своего мощного богатырского крика [Yıldırım, 2007. S. 168]. В реальности стены Гелиболу и других крепостей Фракии были разрушены сильнейшим землетрясением 1354 г., о котором повествуют византийские летописцы и которое облегчило османское завоевание Фракии. Однако в народной памяти природное явление мифологизировалось и в таком виде было сохранено для потомства. Мотив деревянного меча (в целом характерный для вилайет-наме бекташи) не встречается в «Вилайет-наме-и Сейид Али Султан», но зато в нефесах используется неоднократно (агач кылыч, тахта кылыч). В «Вилайет-наме» нет рассказа о битве в «Гусиной долине» (расположенной к востоку от Диметоки), попавшего в нефесы и в народные предания из других источников. В рассказе о погребении лошади Сейида Али Султана в «Вилайет-наме» шейх заставляет землю разверзнуться и поглотить его павшую лошадь (действие происходит на плато Сары-Кызыл, поблизости от будущей обители). 
В народном предании на ту же тему сказано, что Кызыл-Дели сам вырыл могилу для своей лошади, и это место стало в дальнейшем называться Ат-мезар (и, возможно, почитаться как таковое) [Yıldırım, 2007. S. 178]. Некоторые предания не встречаются ни в «Вилайет-наме», ни в нефесах, но сохранились в народной памяти (они привязаны главным образом к каким-то местным реалиям Фракии).

Согласно «Вилайет-наме», Сейид Али Султан, поселившись в окрестностях Диметоки, обратил на праведный путь более 12 тысяч местных жителей [Там же. S. 179]. Поклонники стекались к нему отовсюду. Точное место, на котором была основана обитель, в тексте не указано. Можно понять, что оно находилось где-то между плато Джебель (Челеби) и плато Сары-Кызыл (Сары-Кыз). Время основания дергаха также не уточняется, но по косвенным данным можно сказать, что это вторая половина или самый конец XIV в. Б. Нойан приводит дату 1397 г. [Noyan, 1998. S. 247]. В нефесах бекташи главными ориентирами обители Кызыл-Дели служат гора Танры-дагы и «красная» река Кызыл-Дели. На склонах горы в XVI в. росла роща (кору), как это следует из нефеса Пир Султана Абдала [Öztelli, 2004. S. 176]. В устных фольклорных рассказах передается разговор между Сейидом Али Султаном и Мурадом I, в котором шейх заявляет султану: «Теперь вы стали заниматься грабежом (чапул). Больше мы не останемся рядом с вами. Если хочешь вознаградить нас, дай нам место для жительства (юртлук)». Мурад I выделил землю на берегу реки Кызыл-Дели, и там была построена Нижняя обитель, а несколько позднее - Верхняя [Yıldırım, 2010а. S. 80]. Преемником Сейида Али Султана на ратном поприще «Вилайетнаме» считает Гази Эвренос-бея.

Для бекташи Сейид Али Султан важен прежде всего как связующая нить между Хаджи Бекташем и Балым Султаном, воспитанным в текке Сейида Али Султана (и, вместе с тем, между двумя разными пониманиями мистицизма: «отрешенным» мистицизмом первых бекташи и активным «янычарским» суфизмом XVI в.). В нефесах более позднего времени все эти три личности как будто сливаются в одну («Балым Султан, Кызыл-Дели, Хункар [Хаджи Бекташ]»), символизирующую в своем триединстве «путь бекташи».

Образ Кызыл-Дели был популярным и среди воинов-гази, и среди переселявшихся во Фракию туркмен-полукочевников, и среди дервишей-абдалов. Он восхваляется в диване поэта Садык Абдала (рукопись 1742 г.) $)^{5}$, дервиша, служившего в обители Кызыл-Дели. Рукопись была переписана в с. Искендерийе в Албании Рустем Абдалом. Переписчик не указал времени жизни самого Садык Абдала, но отметил, что его слова - это «слова святого», и приложил к дивану также словарь устаревших слов, ставших непонятными читателям XVIII в. Кроме того, он снабдил каждое стихотворение кратким резюме на персидском языке,

5 | Konya Bölge Yazmalar Kütüphanesi, № 894.35-1. 
хотя не исключено, что эти резюме существовали уже в той рукописи, с которой делал свою копию переписчик. Не так давно диван Садык Абдала был издан в Турции [Gümüşoğlu, 2009], но без научного комментария. В стихах Садык Абдала упоминается «путь бекташи» (рах-и бекташи), ведущий к совершенному наставнику (эту роль Садык Абдал отводит Хаджи Бекташу, Абдалу Мусе и Сейиду Али Султану). Садык Абдал совсем не упоминает Балым Султана (это показывает, что его творчество, вероятно, отражает более раннюю стадию существования традиции бекташи, и сам он, скорее всего, не дожил до эпохи Балым Султана). Садык Абдал говорит, что он получил посвящение от взгляда (назар) Кызыл-Дели:

Как только из милости бросил взгляд Кызыл-Дели, Я обрел возвышенную стоянку, не осталось [во мне] низменных склонностей.

[Ylldırım, 2010b. S. 157, not 4].

В двух «биографических» стихотворениях, вошедших в его диван, Садык Абдал рассказывает о том, как в возрасте 13 лет он случайно услышал беседу двух дервишей-бекташи, одного из которых звали Дервиш Мехмед, и эти слова отпечатались у него в сердце и зажгли в нем «пламя любви». Это пламя не затухало и полыхало все сильнее. В конце концов в 22 года будущий поэт пришел к вратам обители Кызыл-Дели. Там он получил наставление от самого Кызыл-Дели (или от его духа), после чего смог созерцать тайную мудрость, не прибегая к словесному выражению. Взгляд Кызыл-Дели освободил Садык Абдала от душевных мук. Если смотреть «глазами сердца», говорит Садык Абдал, то можно сказать, что дух шейха вселился в его тело и живет в нем, вещает его языком, водит его рукой:

Знай, что все мое видимое существо, с ног до головы, принадлежит ему. $\mathrm{OH}$ - тот, кто говорит моим языком, тот, кто чертит линии моей рукой.

[Y1ldırım, 2010b. S. 158].

Садык Абдал подробно описывает свой приход в обитель КызылДели в жаркий летний день; то, как он сорвал ягоды с тутового дерева, выращенного Кызыл-Дели из сухой ветки, как испил воды из святого источника Кара-пынар и узрел великолепный надгробный памятник (тадж) Кызыл-Дели. Говоря о Хаджи Бекташе и Абдале Мусе, Садык Абдал также утверждает, что они одарили его своим благим взором «из вечности» (эзельден). Кроме имен «трех кутбов» (высочайшего ранга святых) Садык Абдал в своих стихах упоминает других знаменитых представителей «пути бекташи» XV в. - Отмана Баба, Кара Баба (Хы- 
зыра Баба) и Кайгусуза Абдала (о последнем сказано, что он исцелил слепоту и хромоту египетского султана и написал трактат «Дильгуша», который действительно был наиболее популярным и читаемым произведением Кайгусуза Абдала в XV-XVI вв.). Кара Баба считается наследником и первым халифе Отмана Баба (ум. 1478 г.). С другой стороны, Садык Абдал, служивший в обители Кызыл-Дели, должен был быть знаком с выходцем из той же обители - Балым Султаном, если бы он был его современником и жил, по крайней мере, в конце XV - начале XVI в. Следовательно, Садык Абдал, скорее всего, жил несколько ранее, был младшим современником Кайгусуза Абдала и Отмана Баба и умер в 80-90 гг. XV в. Таким образом, его стихи - один из наиболее ранних творческих продуктов обители Кызыл-Дели.

В «Вилайет-наме-и Демир Баба», посвященном болгарскому турецкому святому Демир Баба (XVI в.), принадлежавшему к традиции Отмана Баба, рукопись которого относится к 1619/20 г., рассказывается, что Демир Баба дважды посещал обитель Кызыл-Дели, где получил от потомков последнего в подтверждение своих полномочий грамоту (хила(ет-наме), но тогда же поссорился с некоторыми дервишами-бекташи из этой обители (следовательно, две ветви братства, известные в дальнейшем как челебилер и бабаган, уже разошлись между собой).

Если верить османскому официальному историографу Ашикпаша-заде, учение Хаджи Бекташа принес на османские земли Абдал Myca [Aşıkpaşazâde, 1949. S. 238]. Согласно «Вилайет-наме-и Абдал Муса», Абдал Муса передал «тайну» Хаджи Бекташа (Хаджи Бекташ сырры) своему дервишу Кызыл-Дели, которого он посылал на могилу Хаджи Бекташа для того, чтобы разыскать три его регалии (эманет) и вернуть их «законному» хозяину - Абдалу Mусе [Yıldırım, 2007. S. 121-126]. Абдал Муса вручил Кызыл-Дели деревянный меч и отправил его вместе с войском Гази Умур-паши в походы (газа) против «неверных». Но эти легенды по какой-то причине не нашли никакого отражения в «Вилайет-наме-и Сейид Али Султан», которое вообще не упоминает Абдала Мусу и приводит своего героя напрямую к Хаджи Бекташу. Со своей стороны нефесы бекташи, в том числе и восходящие к XVI в., говорят о переходе «тайны» от Хаджи Бекташа к Абдалу Мусе и затем к Кызыл-Дели:

Ты - царь царей, ты - высочайшая персона,

Ты - рудник всякого знания, царь святых,

Ты - Абдал Муса, ты — сам Кызыл-Дели,

Главой абдалов называют Хаджи Бекташа.

[Öztelli, 2004, s. 196].

Кул Химмет (XVI в.) в своем нефесе говорит, что Хаджи Бекташ передал свой «венец» напрямую Кызыл-Дели (см. выше). В понимании рядовых абдалов личности выдающихся святых сливались в одно целое, 
например «Хункар Хаджи Бекташ Шах Сейид Али», «Абдал Муса Султан Кызыл Вели» и т.п. Чтобы дервиш стал кутбом, в нем должна была проявиться извечная «тайна», передающаяся от имама Али. Наследники этой «тайны» являются носителями одной и той же сокровенной сущности и, по сути дела, — «повторением» или «воплощением» один другого. Каждый из них - Али своей эпохи. Садык Абдал в одном из своих стихотворений сообщает, что Хаджи Бекташ изложил тайны Истины (Хакк) в трактате «Макалят» для всех «влюбленных и преданных» [Yıldırım, 2010b? s. 167]. Он говорит и о том, что Хаджи Бекташ дал свою духовную защиту (химмет) янычарам и подарил им венец в форме буквы алиф (элифи тадж). Он настаивает на глубинном тождестве Хаджи Бекташа и Абдала Мусы:

Тайна Бекташа, как ты знаешь, — также это мой шах Абдал Муса. Он сам был тем шахом; если ты поймешь, тебе этого достаточно.

[Ibid., not 17].

Абдал Муса, согласно его «Вилайет-наме», родился уже после физической смерти Хаджи Бекташа. То же самое могло повториться и в случае с Кызыл-Дели (Сейидом Али Султаном) по отношению к самому Абдалу Мусе, но могло быть и иначе. Из слов Садык Абдала ясно только то, что каждый из них при жизни был кутбом для суфиев своего времени. Садык Абдал называет Кызыл-Дели «победителем двух миров, обладателем силы», которому служат ангелы и подчиняются небесные сферы. После Кызыл-Дели Садык Абдал поминает в своих стихах Отмана Баба, которого он, по-видимому, тоже относит к числу кутбов, но не устанавливает прямой преемственности между ним и Кызыл-Дели. Садык Абдал называет Кызыл-Дели «Завоевателем Рума» (Фатих-и Рум), хотя этот титул в османской истории прочно закрепился за султаном Мехмедом II (1451-1481 гг.). Поэт перечисляет чудеса шейха: он очистил Румелию от воров, разрубил надвое камень своим мечом, заставил потечь источник из сухой земли, прорастил дерево из сухой ветки (те же самые чудеса попали и в «Вилайет-наме-и Сейид Али Султан»). В другом стихотворении Садык Абдала говорится, что Кызыл-Дели Султан «завершил собой все установления (эркан) пути» и что он являет собой совершенного наставника [Yıldırım, 2010b. S. 169]. Садык Абдал утверждает, что его слова будут непонятны для аскета (захид), но для «людей тариката» они послужат путеводной нитью. В стихах Садык Абдала (как и в летописи Ашикпаша-заде) сообщество бекташи обозначается словом бекташийан. Он призывает «ищущих» приходить в текке бекташи и там оставаться навсегда, прислуживая «посвященным» и обретая «сердечную радость» (гёнюль сафасы).

Последователи Хаджи Бекташа (культ которого был весьма популярен среди так называемых «абдалов Рума») в XIV-XV вв. активно переселялись на Балканский полуостров. Мы знаем, что принц Сулей- 
ман-паша, завоевав в 1355 г. часть территории Фракии, сразу же обратился к своему отцу Орхану с просьбой прислать из Анатолии людей для поселения на новых землях [Aşıkpaşazâde, 1949. S. 124]. Наиболее мобильной частью анатолийского населения, как известно, были полукочевники-туркмены (османское правительство с их помощью старалось укреплять свои рубежи). Некоторые из них на Балканах оседали в сельской местности и начинали заниматься земледелием, прочие же сохраняли полукочевой образ жизни в течение нескольких веков. Этих людей стали в XIV в. заносить в отдельные реестры под названием «юрюки». Для этих военизированных переселенцев фигура воинственного Сейида Али Султана, вероятно, оказалась ближе и «роднее», чем образ смиренного, погруженного в себя Хаджи Бекташа Вели.

В позднеосманском жизнеописании Вели Баба (дервиш, живший в XVII в.) Сейид Али Султан носит прозвище Узун Эр («Высокорослый воин»). Отцом его назван некий Сейид Джафер, который служил Осману Гази и был предательски убит византийцами на свадьбе в Биледжике (1290 г.). Сам Сейид Али выступает как правая рука Сулеймана-паши и участвует вместе с ним в походе на Румелию, предпринятом в 1354 г. Сейида Али сопровождают его сын Гюль Баттал Гази и внук Сейид Хусейн. Они переправились через пролив на плоту (сал). Сын и внук Сейида Али погибли при взятии Гелиболу и были похоронены в этом городе. Сам же он, повоевав еще некоторое время, якобы уплыл на корабле в Анатолию, в некую «блаженную обитель» (дергах-и шериф), где и скончался в 1364 г. в возрасте 75 лет. Его предполагаемая гробница находится близ селения Улугбей в окрестностях г. Испарта. Живший там же Вели Баба был потомком Сейида Али в пятом колене (на самом деле за 250 лет, которые их разделяют, могло смениться 7-10 поколений). [Noyan, 1996. S. 165-169]. Автор сочинения, скорее всего, не был знаком с текстом «Вилайет-наме-и Сейид Али Султан» и дал волю своей фантазии. Однако наличие общин последователей Кызыл-Дели в Анатолии показывает, что этот персонаж оставил после себя память и в Малой Азии (хотя разобраться в его «анатолийской» биографии, плотно окутанной легендами, еще сложнее, чем в «румелийской»).

Обитель Кызыл-Дели в Диметоке, судя по архивным документам, была одной из богатейших в округе. В ней служило большое число дервишей. В начале XIX в. обители принадлежало 24 деревни, семь вакуфных мельниц, она владела 2500 головами мелкого рогатого и 200 головами крупного рогатого скота. В обители подвизалось около 150 безбрачных дервишей-бекташи, не считая работников и слуг. В деревнях, приписанных к текке, проживало еще около 700-800 человек, претендовавших на то, что они являются әр-заде (потомками КызылДели), и отказывавшихся на этом основании платить десятину (ушр) [Yıldırım, 2010b. S. 173-174].

Мехмед II в середине XV в. изъял земли обители Кызыл-Дели из вакфа и передал их в условное держание (тимар). Эти действия султа- 
на (аналогичные тому, что он предпринимал и в других частях своей империи) объясняются его политикой централизации и стремлением сделать государственной идеологией «книжный» ислам суннитского толка. Но его сын Баязид II возвратил земли текке Кызыл-Дели и вновь позволил обратить их в вакф, признав права так называемых «сыновей Кызыл-Дели» (опись тахрир 1486 г.). Только в описи 1568-1569 гг. содержатся некоторые сведения о самом Кызыл-Дели: сказано, что он прибыл в Румелию во время первых османских завоеваний и в 1402 г. получил от Баязида I деревни Дары Бюкю, Тыфиллю (Тырфуллу Вираны) и Бююк Виран в качестве наследственного вакфа (что подтверждается грамотой (битu) принца Мусы Челеби от 1412 г., сохранившейся в Османском архиве премьер-министра).

Традиция бекташи утверждает, что будущий шейх Балым Султан был воспитан в текке Кызыл-Дели и даже был там настоятелем до 1501 г. Но в налоговых описях 1486, 1519, 1530 гг. его имя не упоминается (из чего можно заключить, что, по крайней мере, Балым Султан не был в этот период распорядителем вакфа Кызыл-Дели и не имел в нем своей доли). В дефтере 1486 г. встречается имя Мюрселя, сына Кайыр-хана (отца Балым Султана, по мнению бекташи, звали Мюрсель). Но этот Мюрсель был всего лишь зависимым крестьянином (райятом) обители, владевшим только упряжкой волов [Там же. S. 175]. Нужно признать, что данные вакуфных описей никак не коррелируются со сведениями, почерпнутыми из традиционной истории бекташи. Бекташи не знают имен «потомков» Кызыл-Дели, приведенных в османских описях (кроме Шабана Деде/Шабана Абдала, умершего между 1456 и 1486 гг.).

Исходя из архивных данных, Р. Йылдырым делает предположение, что Шабан Деде был настоятелем текке Кызыл-Дели, затем его сменил его сын Синан Деде, но делами, связанными с имуществом вакфа, занимался не он, а его брат Гюльшехри, на земельном участке (мезра) которого стояла гробница Кызыл-Дели (опись 1486 г.). С другой стороны, Синан Деде и Гюльшехри Деде могли и не приходиться сыновьями Шабану Деде, а быть, скажем, его племянниками, двоюродными братьями и т.п. В записях 1519 г. фигурирует только Синан Деде (Гюльшехри Деде к этому времени уже умер). В описи 1568-69 г. вновь упоминается деде-и эвкаф («деде вакфов»), но его имя не приводится [Там же. S. 176]. В ранних документах распорядители вакфа Кызыл-Дели не титулуются сейидами. Однако в правительственном распоряжении (хюкюм) от 1568 г. правнук Шабана Деде Мирза уже носит прозвище «Сейид». В эдикте султана Ибрахима от 1641 г. несколько потомков Кызыл-Дели титулуются сейидами, причем говорится, что им выданы новые патенты-берат (подтверждающие их происхождение от Пророка) [Göklbilgin, 2008. S. 186]. В XVIII в. именовать потомков Кызыл-Дели сейидами стало уже традицией. В османских документах всегда говорится только о Кызыл-Дели (имя Сейид Али Султан не употребляется, исключая поздние документы конца XIX в.). Титул «деде» обычно при- 
менялся в отношении настоятеля (пост-нишин) обители. Скорее всего, потомки Кызыл-Дели (подлинные или мнимые) занимали должности и настоятеля текке, и распорядителя вакфа Кызыл-Дели (как это следует из архивных записей XVIII в.).

B XVI в., судя по данным «Вилайет-наме-и Демир Баба», по приказу султана Сулеймана Кануни текке было перенесено на другое место, вверх по склону горы, а могила Кызыл-Дели Пехливана («Богатыря», «Борца») долгое время оставалась неухоженной и заросла кустарником. Ее затем расчистил некий Сейфуллах, построивший там uмapem (богоугодное заведение). С тех пор здесь снова стали приноситься жертвы. Между двумя текке началось соперничество. Демир Баба во время своего пребывания в Диметоке поддерживал хорошие отношения с «главой дервишей» (сер-дервишан) Нижнего текке, но насельники Верхнего текке («торлаки») во главе с «главным торлаком» (баu-торлак) враждовали с дервишами из Нижнего текке. «Глава дервишей» называл своего конкурента «плешивым иудеем» (келеш чыфыт), а тот в ответ честил его «грешным тюрком, не соблюдающим ни омовения, ни намаза» [Noyan, 1976. S. 112]. Потомки Кызыл-Дели (эр-заде) обитали, вероятнее всего, в Нижнем текке, и именно от одного из них Демир Баба получил грамоту, подтверждавшую его полномочия. Настоятель же Верхнего текке окрестил Демир Баба «свинотюрком» и велел не пускать его в свою обитель. Дервиши Верхнего текке в «Вилайет-наме-и Демир Баба» характеризуются как «торлаки с синими и зелеными глазами, опоясанные фиценом, с бекташийскими колпаками (кисве) на головах, с лиловыми лицами [посиневшими от пьянства? - Ю. А.]», то есть как «типичные» бекташи, какими их представляло себе османское общество того времени [Там же. S. 114].

Визит Демир Баба в обитель Кызыл-Дели состоялся в 30-40 гг. XVI в. (после смерти его наставника Ак-Йазылы Султана). Но османские архивные документы отмечают наличие двух текке Кызыл-Дели (Верхнего и Нижнего) только в 1819 г. (как и наличие у каждого текке своего собственного настоятеля). В Верхнем текке, по-видимому, было устроено и новое тюрбе для самого Кызыл-Дели. Вероятнее всего, это было результатом какого-то раскола среди дервишей обители. «Раскольники» отказались признавать авторитет потомков Кызыл-Дели и настаивали на приоритетности духовного общения со святым перед родством (что соответствует учению Балым Султана). Эти дервиши обвиняли Демир Баба в том, что он присягнул Отману Баба, и значит, он - не бекташи. Более того, они даже попытались физически устранить Демир Баба, но деде Нижнего текке встал на его сторону, сказав, что род Отмана Баба, как и род Хаджи Бекташа, восходит к Седьмому имаму шиитов и заслуживает почтения. Для того чтобы прекратить раздоры между дервишами, в обитель Кызыл-Дели был приглашен челеби из числа потомков Хаджи Бекташа. Обе враждующие стороны собрались на празднество, устроенное Демир Баба 
по случаю заклания им курбана. «Верхних» дервишей поддерживали находившиеся в обители двое янычар, которые в тексте именуются «цыганским отроком» и «еврейским отроком». Именно они и собирались напасть на Демир Баба [Там же. S. 118-121]. С другой стороны, обитатели Нижнего текке в тексте нигде не названы «бекташи». С большой долей вероятности мы вслед за Р. Йылдырымом можем связать раскол в обители Кызыл-Дели, произошедший в первой половине XVI в., с деятельностью Балым Султана и поддерживавшей его партии торлаков, хотя само имя «Второго пира» бекташи нашим источникам остается неизвестным (или сознательно ими обходится молчанием).

Сторонники Балым Султана постоянно пытались доказать его связь с предшествующим «путем бекташи» и, в частности, его преемственность с Кызыл-Дели. Так, живший в XVI в. поэт Казак Абдал, ученик Балым Султана, восхвалял его такими словами:

Произошедший (букв. «пробужденный»)
от моего Кызыл-Дели Султана,
Весь в зеленых [одеждах] закутан,
Опирающийся на порог моего пира,
Султан Балы, сын Мюрселя Деде.

[Gölpınarl1, 1992. S. 108-109.]

Пир Султан Абдал, также живший в XVI в., в своем нефесе подчеркивает связь Балым Султана с обителью Кызыл-Дели:

Принесли чашу от светлоглазого Шаха, Ты сам испей, возлюбленный, и мне дай. Балым Султан прибыл от Кызыл-Дели, Ты сам испей, возлюбленный, и мне дай!

[Öztelli, 2004. S. 222.]

Но личность самого Балым Султана продолжает оставаться загадкой для историков. По легенде его отец Мюрсель Баба (Деде) женился в 90-летнем возрасте на болгарской царевне, и от этого брака на свет появился Балым Султан (таким образом, его последователи, как и его противники, имели полное право не считать его «тюрком»; может быть, они даже гордились его необычным происхождением). Царевна забеременела мистическим образом (Мюрсель Баба обмакнул свой палец в чашку с медом и сунул палец ей в рот); можно предположить, что она была беременной и до встречи с Мюрселем Баба, и что Балым Султан вообще по крови не имел никакого отношения к «тюркам». Не потому ли и его ученики-торлаки в «Вилайет-наме-и Демир Баба» с таким презрением относятся к «тюркам» и сами описаны в тексте как совершенно не похожие на них «чужаки» с голубыми и зелеными глазами? Однако, дальнейшее развитие конфликта между Верхним и Нижним текке 
Кызыл-Дели от нас ускользает, так как соответствующие материалы в османских источниках пока не обнаружены или не исследованы.

О духовной жизни обители Кызыл-Дели в XVIII в. мы можем судить на основе записей шейха Сырры Рифаи аль-Алеви, одного из наставников братства рифаийа, который в 1799 г. участвовал в обрядах, проводимых в мейдане этой обители. В те времена отношения между османскими суфиями, принадлежавшими к разным тарикатам, были еще очень «чистосердечными», и они могли присутствовать во время проведения мистериальных ритуалов других братств. Записи шейха Сырры были включены в его трактат «Рисале-и лахутийе», рукопись которого была переписана в 1868 г. шейхом Ахмедом Бедр эд-Дином Халвети. В этих записях шейхом (пост-нишин) Верхней обители назван Сейид Али Деде, а настоятелем Нижней обители - Сейид Халиль Деде (причем почетные османские титулы «благочестивый из благочестивых», «гордость великих мужей», «халифе своего времени» приводятся только по отношению к Сейиду Али Деде). Шейх Сырры именует самого святого, в честь которого построены оба текке, «наш повелитель Кызыл-Вели Султан Сейид Али», соединяя оба его прозвища). В трактате «Рисале-и лахутийе» излагаются ритуалы (әркан), принятые в обители Кызыл-Дели, и дается толкование символов тариката6.

К концу XVIII в. относится также трактат «Уйун аль-хидайе» Ресми Али Баба Гириди, современника шейха Сырры ${ }^{7}$. На последней странице Ресми Али сообщает, что он - «один из рабов Сейида Али Султана». Его взгляды представляют собой смешение идей Ибн аль-Араби с традиционным почитанием Алидов. В трактате подчеркивается роль совершенного наставника при прохождении мюридом стоянок «пути».

В 1826 г. в связи с роспуском янычарского корпуса и гонениями на бекташи, мутасаррыф Чирмена Эсад-паша направил в текке КызылДели 70-80 вооруженных всадников, чтобы обыскать обитель на предмет укрывшихся там беглых янычар. Этот отряд фактически захватил текке и расположился там. Султан Махмуд II требовал от своих сановников решительных действий в отношении обителей бекташи (которые он презрительно называл «винодельнями» - шербет-хане), но они не спешили приступать к репрессиям против бекташи в провинциях, аналогичным тем, что имели место в столице. Предполагалось имущество текке конфисковать, дервишей-бекташи сослать в отдаленные места, здания обители обратить «на пользу государства» (т.е., в мечеть или в казарму для военнослужащих). Из Стамбула в обитель КызылДели был направлен правительственный уполномоченный Хаджи Алибей, который должен был на месте ознакомиться с ситуацией и провести в жизнь решения высших властей. Владения и имущество обители Кызыл-Дели, как и других обителей бекташи во Фракии, были описаны 
и конфискованы; некоторое время они управлялись государственными откупщиками (мюльтезим), а затем были проданы частным лицам, но часть имущества была оставлена потомкам Кызыл-Дели и вакф обители сохранен (правда, в меньшем размере). Тюрбе Кызыл-Дели продолжало оставаться местом паломничества (зийаретгах); его смотритель (тюрбедар) получал содержание из доходов вакфа. По-видимому, речь идет о тюрбе, располагавшемся в Нижнем текке [Tozlu, 2010. S. 127-151].

Из архивного документа, датированного 1843 г., мы узнаем, что и Верхнее текке (Мейдан-и бала) продолжало действовать и что тюрбедаром его был утвержден Хусейн Халифе взамен его умершего отца Юсуфа Халифе (Там же. С. 141). Он получал жалованье зерном (пшеницей и рожью) и денежный оклад в размере 20 курушей в месяц. Однако выплата жалованья, как явствует из другого документа, была ему задержана на 7 лет. В 1852 г. Хусейн Деде обратился к наместнику (вали) Эдирне с просьбой позволить его обители выкупить земли, поля и мельницы, проданные после конфискации 1826 г. Из дефтера наместника Мехмеда-паши следует, что в распоряжении Хусейна Деде находилось 25 земельных участков, закрепленных в 1826 г. за семейством потомков Кызыл-Дели, но этого было недостаточно для прокормления странников и паломников, которые вновь стали в массовом порядке посещать обитель (общая площадь его земельных угодий составляла примерно 41 га). Султан и совет министров отказались исполнить прошение Хусейна Деде, ссылаясь на то, что это станет нарушением прежних султанских указов [Там же. S. 142]. Из архивных документов становится ясным, что после изгнания безбрачных дервишей («торлаков») из обители в 1826 г. потомки Кызыл-Дели сумели завладеть и Верхним текке.

После смерти Хусейна Деде, вероятно пользовавшегося большим уважением среди окрестного населения, передавшего в его распоряжение имевшиеся у них на руках документы на владение землями текке, в 1867 г. тюрбедаром был назначен Мехмед Бекташ-эфенди. Султан Абдул-Азиз (1861-1876 гг.) разрешил восстановить текке бекташи. После этого влияние бекташи в Румелии возросло, и этот факт уже в 90-е гг. XIX в. стал вызывать беспокойство местных османских властей. Согласно официальному отчету 1892 г. количество бекташи в окрестностях обители Кызыл-Дели превышало 10 тысяч человек; некоторые из них занимали военные и административные должности. Обитель КызылДели являлась центральной обителью для бекташи Косово, Македонии и Фракии [Maden, 2010. S. 122-125]. Во время наступления войск Антанты в 1918 г. многие бекташи из Западной Фракии переселились вглубь территории Турции, в том числе в Стамбул (где они поселились в азиатской части города, вокруг обители Шахкулу Султан, и в других местах). Новый поток беженцев из Греции отмечался в 1945-1947 гг. в связи с нашествием каракачанов, нападавших на деревни бекташи, окружавшие обитель Сейида Али Султана. 
У современных бекташи Фракии, проживающих в районе между Эдирне и Узункёпрю, четко различаются традиции (сюрек) Сейида Али Султана и Балым Султана (эти различия проявляются в деталях ритуала, в особенностях исполнения нефесов, в использовании тех или иных музыкальных инструментов). На греческой территории последователи Сейида Али Султана расселены примерно в 15 деревнях вокруг Диметоки и на плоскогорье Сечек. В начале августа каждого года они отмечают праздник «масляной борьбы» (йаглы гюреш), покровителем которой признается Сейид Али Султан. Духовным главой этих бекташи считается Мустафа Четин Деде. По мнению Р. Энгина, посетившего обитель Сейида Али Султана в 2004 г., подлинной гробницей Сейида Али Султана является та, что расположена в Верхнем текке [Engin. 2010. S. 367]. Общину Кызыл-Дели возглавляют двенадцать членов совета вакфа. Многие исторические надписи и другие памятники османского времени были, по словам членов общины, уничтожены греками. В Греции проживают в настоящее время 6 деде, служащих на «пути» Кызыл-Дели. С 1826 г. обитель лишена высшего духовного лица (халифе); последний халифе, опасаясь за свою жизнь во время гонений, бежал в Албанию. В общину бекташи принимают всех, получивших посвящение, а не только рожденных от родителейбекташи. В последнее время в обитель стали приезжать паломники и из Болгарии. Болгары-помаки (так наз. чаршамбалы) живут и в районе Диметоки, смешиваясь там с местными «туркменами». Они также были приняты на «путь» Кызыл-Дели.

В Нижнем текке в наши дни из всех бывших там зданий сохранилось только тюрбе, имеющее 6-угольную форму и покрытое сверху каменными плитами, укрывшееся в тени буковых деревьев. Могильные камни с кладбища собраны в тюрбе, большая часть их была разбита греками. На дороге между Нижним и Верхним текке имеется место под названием Саат Махал, где похоронены два гонца из обоих текке, встретившиеся, по преданию, в этом месте и здесь же отдавшие Богу душу в один и тот же миг. Их могилы сохранились. Неподалеку расположено небольшое кладбище, где покоятся деде и баба бекташи (места их погребения увенчаны 12-частными таджами). Верхнее текке окружено полуразрушенной каменной оградой. На территории текке есть два кладбища, заброшенная мечеть, гостевой дом (Паша конагы). На холме Мюрсель Бали находится гробница этого святого и старинное кладбище. Там совершают жертвоприношения во время праздника Касым в начале ноября месяца. Местные жители рассказывают любопытные легенды о Кызыл-Дели, в том числе о его поединке с греческой разбойницей Сары-Кыз, которой он отсек голову мечом (греки похоронили эту голову и стали почитать данное место как святое; там выросли необычные цветы - красные снаружи и фиолетовые изнутри). Ранее в текке якобы было 12 ворот, из них - четверо главных. Электричество было проведено в текке только в 1993 г. [Engin, 2010. S. 382]. 
Личность Сейида Али Султана (Кызыл-Дели) должна рассматриваться не только и не столько в свете оценки исторической достоверности фактов, сообщаемых источниками о его жизни, сколько в свете традиционных представлений о нем, сложившихся у общин бекташи и алевитов, считавших себя его духовными наследниками. Традиция воспринимает Сейида Али Султана как выходца из Хорасана, члена семейства Пророка, получившего благословение от Хаджи Бекташа Вели. Он принес учение Хаджи Бекташа на земли Румелии и дал ему возможность укорениться там. С другой стороны, Сейид Али Султан признается основателем обители и создателем определенной социальной системы, в рамках которой его последователи жили в течение ряда веков на «вновь освоенных» землях Румелии. Авторитет этого шейха (под именем Кызыл-Дели) не оспаривался и османскими властями, даже в период гонений на бекташи в первой половине XIX в. Образ Сейида Али Султана, сложившийся в бекташийской традиции, в целом не противоречит и скудным данным исторических анналов и архивных документов, касающихся его личности. 


\section{Источники и литература}

Abdal Musa, 1999 - Abdal Musa Velâyetnâmesi. Haz. A. Güzel. Ankara, 1999.

Akın, 1968 - Akın H. Aydınoğulları tarihi hakkında bir araştırma. Ankara, 1968.

Aslanoğlu, 2000 - Aslanoğlu İ. Pir Sultan Abdallar. İstanbul, 2000.

Aşıkpaşazâde, 1949 - Aşıkpaşazâde, Derviş Ahmed. Tevârih-i Âl-I Osman. Haz. N. Atsız. İstanbul, 1949.

Aydın, 2008 - Aydın A. Trakya ve Anadolu'da erenler bahçesi. İstanbul, 2008.

Barkan, 1942 - Barkan Ö.L. Osmanlı Imparatorluğu'nda bir iskân ve kolonizasyon metodu olarak vakıflar ve temlikler, I // Vakıflar Dergisi, № 2 (1942).

Beldiceanu-Steinherr, 1971 - Beldiceanu-Steinherr $\dot{I}$. La vita de Seyyid Ali Sultan et la conquête de la Thrace par les Turcs // Proceedings of the $27^{\text {th }}$ International Congress of orientalists, Ann Arbor, 1967. Wiesbaden, 1971.

Beldiceanu-Steinherr, 1999 - Beldiceanu-Steinherr İ. Osmanlı tahrir defterlerinde Seyyid Ali Sultan: Heterodoks İslam'in Türkiye'ye yerleşmesi // Sol Kol: Osmanlı egemenliğinde Via Egnatia (1380-1699). Haz. E. Zahariadou. İstanbul, 1999.

Birdoğan, 1992 - Birdoğan N. Anadolu ve Balkanlar'da Alevî yerleşmesi: ocaklar, dedeler, soyağaçları. İstanbul, 1992.

Birge, 1965 - Birge J.K. The Bektashi Order of dervishes. L., 1965.

Düstur-name-i Enveri, 2003 - Fatih devri kaynaklarından Düstur-name-i Enveri. Osmanlı tarihi kısmı (1299-1466). Haz. N. Öztürk. İstanbul, 2003.

Engin 2010 - Engin R. Refik Engin'in Kızıldeli gezi notları // Türk Kültürü ve Hacı Bektaş Veli, № 53 (kı̧̧ 2010).

Ergun, 1944 - Ergun S.N. Bektâşî şairleri ve nefesleri. İstanbul, 1944.

Faroqhi, 1976 - Faroghi S. Agricultural activities in a Bektashi center: the tekke of Kızıldeli 17501830 // Südost Forschungen, XXXV (München, 1976).

Göklbilgin, 2008 - Gökbilgin M.T. Rumeli'de Yürükler, Tatarlar ve Evlâd-1 Fâtihân. İstanbul, 2008.

Gökbilgin, 1952 - Gökbilgin M.T. XV-XVI. asırlarda Edirne ve Paşa Livâsı: vakıflar, mülkler, mukataalar. İstanbul, 1952.

Gölpınarlı, 1992 - Gölpınarlı A. Alevî Bektaşî nefesleri. İstanbul, 1992.

Gümüşoğlu, 2009 - Gümüşoğlu D. (haz.). Sâdık Abdâl Divânı. İstanbul, 2009.

Hezarfen, 2006 - Hezarfen A. Tarihi belgeler ıșığında Kızıdelı Sultan (Seyit Ali Sultan). İstanbul, 2006. Kafadar, 1995 - Kafadar C. Between two worlds: the construction of the Ottoman State. Berkley, LosAngeles, London, 1995.

Kavak, 2006 - Kavak A. Menkıbelerle Kızıldeli Sultan ve Dimetoka kazasındaki dergâhı. Komotini, 2006.

Kaya, 2002 - Kaya D. Sivas kaynaklı cönklerde Kızıldeli // Uluslararası Türk Dünyası İnanç önderleri kongresi. Ankara, 2002.

Koca Ş., 2005 - Koca Ş. Dimetoka'da bir erenler ocağı: Seyyid Ali Sultan - Kızıldeli (Microdorian) Bektaşı Dergâhı // Bektaşılık ve Bektaşî Dergâhları. Haz. A. Aydın. İstanbul, 2005. 
Koca T., 1990 - Koca T. Bektaşi Alevi şairleri ve nefesleri. İstanbul, 1990.

Kosteneçki, 2008 - Kosteneçki K. Stefan Lazareviç-Yıldırım Bayezid'in emrinde bir Sırp despotu. Haz. H. Mevsim. İstanbul, 2008.

Kumahmedoğlu, 1948 - Kumahmedoğlu N. Konya ve çevresinde bir gezi notları // Konya, № 116-117 (Haziran -Temmuz 1948).

Maden 2010 - Maden F. Kızıldeli Sultan tekkesinin kapatılması (1826) ve yeniden faaliyete başlaması // Türk Kültürü ve Hacı Bektaş Veli, № 53 (k1ş 2010).

Noyan, 2000 - Noyan B. Bütün yönleriyle Bektaşîlik ve Alevîlik. Cilt III. Ankara, 2000.

Noyan, 1999 - Noyan B. Seyyid Ali Sultân (Kızıl Deli Sultân) Velâyetnâmesi. Ankara, 1999.Noyan, 1998

- Noyan B. Bütün yönleriyle Bektaşilik ve Alevilik. Cilt I. Ankara, 1998.

Noyan, 1996 - Noyan B. Veli Baba Menakıbnamesi. İstanbul, 1996.

Noyan, 1976 - Noyan B. Demir Baba Vilâyetnamesi. İstanbul, 1976.0cak, 1997 - Ocak A.Y. Kültür tarihi kaynağı olarak menâkıbnâmeler. Ankara, 1997.

Ocak, 1992 - Ocak A.Y. Osmanlı Imparatorluğunda marjinal Sufilik: Kalenderîler. Ankara, 1992.

Oytan, 2007 - Oytan M.T. Bektaşiliğin içyüzü. İstanbul, 2007.

Öz, 1941 - Öz T. Murat I ile Emir Süleyman'a ait iki vakfiye // Tarih Vesikaları Dergisi, 1/4 (1941).

Özgül, 2010 - Özgül V. 16. yüzyıl öncesinde Dimetoka, Kızıl Deli ve Balabanlılar // Türk Kültürü ve Hacı Bektaş Veli, № 53 (kış 2010).

Öztelli 2004 - Öztelli C. Pir Sultan Abdal. Bütün şiirleri. İstanbul, 2004.

Şahin, 2009 - Şahin H. Seyyid Ali Sultan // TDV İslâm Ansiklopedisi. Cilt 39. İstanbul, 2009.

Şahin, 2008 - Şahin H. Tarih kaynağı olarak evliya menâkıbnâmeleri // Prof. Dr. Işın Demirkent anisina. İstanbul, 2008.

Tozlu 2010 - Tozlu S. Osmanlı arşiv belgelerine göre Kızıldeli (Seyyid Ali Sultan) zaviyesi (1826-1852)

// Türk Kültürü ve Hacı Bektaş Veli, № 53 (kış 2010).

Viranî, 1998 - Viranî Divânı ve Risalesi (Buyruğu). Der. A.A. Atalay Vaktidolu. İstanbul, 1998.

Yıldırım, 2010a - Yıldırım R. Bektaşî-Alevî geleneğine gore Seyyid Ali Sultan // Türk Kültürü ve Hacı Bektaş Veli, № 53 (kış 2010).

Yıldırım, 2010b - Yıldırım R. Muhabbetten tarikata: Bektaşî tarikatı́nın oluşum sürecinde Kızıldeli'nin rolü // Türk Kültürü ve Hacı Bektaş Veli, № 53 (k1ş 2010).

Yıldırım, 2007 - Ylldırım R. Seyyid Ali Sultân (Kızıl Deli) ve Velâyetnâmesi. Ankara, 2007. 